\title{
COMPARATIVE STUDY OF TWO MODES OF GASTROESOPHAGEAL REFLUX MEASURING: conventional esophageal pH monitoring
and wireless $\mathrm{pH}$ monitoring
}

\author{
Rimon Sobhi AZZAM, Rubens A. A. SALLUM, Jeovana Ferreira BRANDÃO, \\ Tomás NAVARRO-RODRIGUEZ and Ary NASI
}

\begin{abstract}
Context - Esophageal pH monitoring is considered to be the gold standard for the diagnosis of gastroesophageal acid reflux. However, this method is very troublesome and considerably limits the patient's routine activities. Wireless $\mathrm{pH}$ monitoring was developed to avoid these restrictions. Objective - To compare the first 24 hours of the conventional and wireless pH monitoring, positioned $3 \mathrm{~cm}$ above the lower esophageal sphincter, in relation to: the occurrence of relevant technical failures, the ability to detect reflux and the ability to correlate the clinical symptoms to reflux. Methods - Twenty-five patients referred for esophageal $\mathrm{pH}$ monitoring and with typical symptoms of gastroesophageal reflux disease were studied prospectively, underwent clinical interview, endoscopy, esophageal manometry and were submitted, with a simultaneous initial period, to 24-hour catheter $\mathrm{pH}$ monitoring and 48-hour wireless pH monitoring. Results - Early capsule detachment occurred in one (4\%) case and there were no technical failures with the catheter $\mathrm{pH}$ monitoring $(P=0.463)$. Percentages of reflux time (total, upright and supine) were higher with the wireless $\mathrm{pH}$ monitoring $(P<0.05)$. Pathological gastroesophageal reflux occurred in $16(64 \%)$ patients submitted to catheter and in $19(76 \%)$ to the capsule $(P=0.355)$. The symptom index was positive in $12(48 \%)$ patients with catheter $\mathrm{pH}$ monitoring and in $13(52 \%)$ with wireless $\mathrm{pH}$ monitoring $(P=0.777)$. Conclusions -1$)$ No significant differences were reported between the two methods of $\mathrm{pH}$ monitoring (capsule vs catheter), in regard to relevant technical failures; 2) Wireless $\mathrm{pH}$ monitoring detected higher percentages of reflux time than the conventional $\mathrm{pH}$-metry; 3) The two methods of $\mathrm{pH}$ monitoring were comparable in diagnosis of pathological gastroesophageal reflux and comparable in correlating the clinical symptoms with the gastroesophageal reflux.
\end{abstract}

HEADINGS - Gastroesophageal reflux. Esophagitis, peptic.

\section{INTRODUCTION}

Gastroesophageal reflux disease (GERD) is defined by our medical community as: "a chronic condition resulting from the reverse flow of gastroduodenal contents into the esophagus and/or adjacent organs, causing a variable range of esophageal and/or extraesophageal signs and/or symptoms, with or without tissue damage ${ }^{(20)}$ "'

It is a condition of great medical and social importance due to its high and growing incidence, causing long-term symptoms, which considerably affect the patients' quality of life. It is estimated that GERD affects approximately $20 \%$ of the adult population in the United States and Europe ${ }^{(29)}$.

Upper gastrointestinal (GI) endoscopy and esophageal $\mathrm{pH}$ monitoring are the methods directly linked to GERD diagnosis. The first method identi- fies forms of the disease causing esophagitis, allowing material collection for histologic examination, while the second helps diagnosing pathological gastroesophageal reflux (GER).

Esophageal $\mathrm{pH}$ monitoring, developed in the 1960 s, was introduced into clinical practice in the 70 's. Initially, a glass $\mathrm{pH}$ probe was used in inpatients. A development of this technique was introduced in the early 80 's, with the use of flexible catheters and portable esophageal $\mathrm{pH}$ recorders in an outpatient setting. In the late 80 's, another important feature, the symptom index, was added to this method ${ }^{(34)}$.

Prolonged esophageal $\mathrm{pH}$ monitoring enabled a better understanding of GERD. It is indicated for a practical approach, providing details of gastroesophageal and pharyngolaryngeal acid reflux, while associating clinical complaints to reflux episodes. However, there are some limitations: substantial discomfort, 
restriction of routine activities, and non-identification of pathological reflux in a considerable portion of patients with clinical and endoscopic evidence, suggestive of reflux.

Because the conventional esophageal $\mathrm{pH}$ monitoring is associated with discomfort, patients tend to exhibit reduced food intake and behave differently during the monitored period $^{(7,19)}$. Normal values of esophageal $\mathrm{pH}$ monitoring, in patients with endoscopic esophagitis, ranges from $17 \%$ to $31.4 \% \%^{(3,5,14,15,17,21,22,28)}$. As a result, a normal $\mathrm{pH}$ monitoring does not exclude GERD diagnosis ${ }^{(3)}$.

A wireless esophageal $\mathrm{pH}$ monitoring system was developed in an attempt to improve the diagnostic sensitivity of the method, since it is better tolerated and allows a longer period of monitoring. Bile and multichannel intraluminal impedance $\mathrm{pH}$ monitoring (MII-pH) analyze other forms of GERD-related symptoms not assessed by $\mathrm{pH}$ monitoring: bile reflux and "non-acid" reflux, respectively.

Although wireless esophageal $\mathrm{pH}$ monitoring may cause chest discomfort because of the capsule, it is believed to be better tolerated than the conventional esophageal $\mathrm{pH}$ monitoring. It is believed that wireless esophageal monitoring may help provide better diagnostic sensitivity of GER, as it does not limit patient daily activities and allowing for longer periods of monitoring. However, there are no local and only a few international publications available, when it comes to the simultaneous comparative study of the wireless esophageal monitoring system and the conventional esophageal $\mathrm{pH}$ monitoring.

\section{Objective}

The objective is to compare the first 24 hours of the $\mathrm{pH}$ monitoring results, with and without catheter, positioned $3 \mathrm{~cm}$ above the lower esophageal sphincter (LES), with regard to: occurrence of technical failures during monitoring; ability to detect gastroesophageal acid reflux; ability to diagnose pathological gastroesophageal reflux; and the ability to relate clinical complaints to reflux episodes.

\section{METHODS}

Patients referred to the Esophageal Functional Investigation Laboratory of the Digestive System Surgery Department (Hospital das Clínicas da Universidade de São Paulo, São Paulo, SP, Brazil) were prospectively screened for 7 consecutive months, for esophageal $\mathrm{pH}$ monitoring.

Inclusion criteria were: heartburn and/or regurgitation as the main clinical complaint; at least 18 years of age; recent upper GI endoscopy (within the last 2 months); interruption in the administration of proton pump inhibitors for 7 days preceding the $\mathrm{pH}$ monitoring; and signature of the free and informed consent form. Exclusion criteria were: esophageal diverticula, strictures and varices; hiatal hernia greater than or equal to $3 \mathrm{~cm}$; erosive esophagitis Los Angeles grades $\mathrm{C}$ or $\mathrm{D}$; Barrett's esophagus; and neoplasms, obstructive diseases or previous surgery of the gastrointestinal tract.

All patients underwent: clinical interview, nasal and oral esophageal manometry, $\mathrm{pH}$ monitoring with and without catheter for 24 and 48 hours, respectively, with simultaneous initial period.

The following GERD complaints were investigated during clinical interview: typical (heartburn and regurgitation), atypical (chest pain and globus sensation), and extraesophageal (cough, asthma, dysphonia and hem).

All patients underwent upper GI endoscopy at the Gastrointestinal Endoscopy Department of the Hospital das Clínicas da Faculdade de Medicina da Universidade de São Paulo. The presence of erosive esophagitis and hiatal hernia were assessed. The Los Angeles grade system was used for the characterization of esophagitis; the protrusion of part of the stomach 2 or more centimeters into the diaphragm, during deep inspiration, was considered hiatal hernia.

\section{Esophageal manometry}

Before $\mathrm{pH}$ monitoring, patients underwent two manometric examinations to identify the LES: nasal and oral.

Nasal esophageal manometry was performed conventionally, with nostrils local anesthesia using $2 \%$ lidocaine gel and a $4.5 \mathrm{~mm}$ (diameter) polyvinyl, flexible catheter, with eight recording channels perfused with $0.6 \mathrm{~mL}$ distilled water flow per minute. A complete esophageal manometry was performed; however, for the purpose of this study, only the location (distance from the nostril) of the LES was considered. The oral manometry was performed with local oropharynx anesthesia using $10 \%$ liquid aerosol lidocaine, with the same equipment used for the nasal manometry, for location (distance from the upper dental arch) of the LES.

\section{Esophageal pH monitoring}

After evaluating the distance of the LES in relation to the nostril and to the upper dental arch through manometry, a catheter of the conventional esophageal $\mathrm{pH}$ monitoring system was introduced, followed by the capsule of the wireless esophageal $\mathrm{pH}$ monitoring. Each patient underwent conventional $\mathrm{pH}$ monitoring for 24 hours, and wireless $\mathrm{pH}$ monitoring for 48 hours, with simultaneous monitoring recording starting time.

The equipment used for the conventional $\mathrm{pH}$ monitoring consisted of: portable recording device (Medtronic/Synetics, USA), calibration solutions and $\mathrm{pH}$ monitoring catheter (Alacer, Brazil). The $2.1 \mathrm{~mm}$ in diameter catheter displayed two antimony sensors ( $2 \mathrm{~cm}$ away from each other) for $\mathrm{pH}$ registration, and an external reference electrode. The distal sensor was positioned $3 \mathrm{~cm}$ above the superior border of the LES, identified through nasal esophageal manometry. By internationally accepted standards, the proximal sensor was positioned $5 \mathrm{~cm}$ above the superior border of the LES.

The wireless monitoring system equipment (Bravo, Medtronic/Synetics, USA) consisted of: portable $\mathrm{pH}$ monitoring recording device, calibration solutions, $\mathrm{pH}$ monitoring capsule, and capsule delivery device. The $\mathrm{pH}$ monitoring capsule used contained an antimony sensor, sensitive to $\mathrm{pH}$ changes, and an internal reference electrode. The capsule sensor was systematically calibrated before each test, using the same solutions at $\mathrm{pH} 7$ and $\mathrm{pH} 1$. The capsule, measu- 
ring $6.0 \times 6.3 \times 26.0 \mathrm{~mm}$ was inserted through the mouth and positioned in the esophagus, $3 \mathrm{~cm}$ above the superior border of the LES, identified by oral manometry and at the same level as the conventional catheter's distal sensor. The suction system was applied by a vacuum pump $(510 \mathrm{~mm} \mathrm{Hg}$ during $60 \mathrm{~s}$ ) and the esophagus mucosa penetrated into the capsule compartment ( $4 \mathrm{~mm}$ in diameter). The pin was released, transfixing the suctioned mucosa, while attaching the capsule to the esophageal wall. The vacuum was turned off and the capsule released from the distal end of the delivery device, which was removed. The $\mathrm{pH}$ recording was started and transmitted by radio waves (telemetry) to the portable recording device.

Patients were advised to try to maintain their daily activities, to fill out the $\mathrm{pH}$ monitoring $\log$, and to return to the laboratory after 24 hours (1st day) to remove the $\mathrm{pH}$ monitoring system, and again after another 24 hours (2nd day) to remove the external recording device of the wireless $\mathrm{pH}$ monitoring system.

It is important to note that the data recorded by both the conventional and the wireless $\mathrm{pH}$ monitoring system sensors positioned $3 \mathrm{~cm}$ above the superior border of the LES were compared. The data related to the conventional $\mathrm{pH}$ monitoring sensor positioned $5 \mathrm{~cm}$ above the superior border of the LES was used to complete the $\mathrm{pH}$ monitoring routine report, enabling the continuation of the patient's usual treatment. However, in this study, we do not compare the results recorded 5 and $3 \mathrm{~cm}$ above the superior border of the LES.

To compare the two types of esophageal $\mathrm{pH}$ monitoring, the following parameters were considered: occurrence of relevant technical failures during the monitoring period; ability to detect gastroesophageal acid reflux; and ability to relate clinical symptoms with acid reflux episodes.

Any incident preventing or impairing the proper monitoring of reflux, such as early capsule drop, extended interference periods and absence of signal, were all considered relevant technical failures.

The data recorded over the first day of monitoring was used to evaluate the acid reflux detection ability; the following parameters were considered: percentage of total reflux time, percentage of reflux time in upright position, percentage of reflux time during supine position and characterization of the reflux pattern (physiological or pathological). It is noteworthy that parameters of normality for the characterization of pathological reflux were established by measuring reflux $5 \mathrm{~cm}$ above the LES and were only used in this study as reference values. The normal parameters used were: rate of total reflux time up to 4.5 , rate of reflux time in an upright position up to 8.4 , and rate of reflux time in a supine position up to $3.5^{(12)}$.

The patient was considered to be affected by pathological gastroesophageal reflux if: any of the three percentages of reflux time adopted were at levels higher than normal; or had quantitatively normal reflux, but with a significant relationship with the symptoms. The relationship between clinical complaint and gastroesophageal acid reflux was assessed by the symptom index and considered positive when equal or greater than $50 \%{ }^{(34)}$.
The evaluation of spontaneous detachment of the wireless system capsule from the esophageal wall was performed by a lateral chest X-ray, on the 30th day after its insertion.

This study was approved by the Ethics Committee for Analysis of Research Projects of the Clinical Hospital of the São Paulo University Medical School (number 1079/06).

For the statistical study, conducted at the Laboratory of Statistics and Epidemiology, Department of Gastroenterology, São Paulo University Medical School, the following tests were used: Fisher's exact test, Wilcoxon ratio, paired $t$-test and bilateral test. The rejection level for the null hypothesis was set at 0.05 .

\section{RESULTS}

Twenty-five patients were included, 21 (84\%) of which were female. Ages ranged from 34 to 73 years (average 52.4). All patients had as predominant symptom the typical GERD complaints. Sixteen (64\%) patients had atypical complaints, and $10(76 \%)$ had associated extraesophageal complaints. Upper GI endoscopy revealed erosive esophagitis in $8(32 \%)$ patients and hiatal hernia in $11(44 \%)$.

There was no significant difference between the two types of $\mathrm{pH}$ monitoring concerning technical failure during examination $(P=0.463)$. An early capsule drop occurred in one $(4 \%)$ patient during the wireless method exam; there was no relevant technical failure in the group monitored with a catheter.

Regarding the detection capacity of gastroesophageal acid reflux (Table 1), there was significant difference between the two types of $\mathrm{pH}$ monitoring, with a higher reflux detection rate in patients being monitored with the wireless system (percentage of total reflux, $P=0.001$; reflux in upright position, $P=0.020$, and reflux in supine position, $P=0.023$ ).

With regard to the reflux pattern, the conventional method detected pathological gastroesophageal reflux in $16(64 \%)$ patients, while the wireless method in $19(76 \%)$ patients. However, such difference did not reach statistical significance $(P=0.355)$.

TABLE 1. Comparison of reflux time rate between the two methods of esophageal $\mathrm{pH}$ monitoring, positioned $3 \mathrm{~cm}$ above the lower esophageal sphincter, in 25 patients

\begin{tabular}{lccccc}
\hline $\begin{array}{l}\text { pH monitoring } \\
\text { (day 1) }\end{array}$ & Min & Max & Median & Average & $P$ \\
\hline \multicolumn{7}{c}{ Total reflux time rate } \\
Conventional & 0.1 & 13.8 & 4.1 & 5.0 & $0.001 *$ \\
Wireless & 0.1 & 21.4 & 6.1 & 7.0 & \\
\hline \multicolumn{7}{c}{ Reflux time rate in upright position } \\
Conventional & 0.5 & 13.6 & 6.2 & 6.3 & $0.020 * *$ \\
Wireless & 0.1 & 19.2 & 7.4 & 7.8 \\
\hline \multicolumn{7}{c}{} \\
Conventional & 0.0 & 23.4 & 0.10 & 3.5 & $0.023 *$ \\
Wireless & 0.0 & 31.9 & 1.30 & 5.8 \\
* Wilcoxon test; ** Paired $t$-ratio test; Min $=$ minimum;
\end{tabular}

* Wilcoxon test; $* *$ Paired $t$-ratio test; Min = minimum; Max = maximum; Conventional = conventional esophageal $\mathrm{pH}$ monitoring; Wireless = wireless esophageal $\mathrm{pH}$ monitoring 
As for the ability to relate clinical symptoms with reflux, out of the 25 patients studied, $20(80 \%)$ exhibited symptoms during monitoring. The symptom index could be calculated in those patients with symptoms. There was no significant difference between the two types of $\mathrm{pH}$ monitoring systems, when it comes to the positivity of the symptom index $(P=$ 0.777) (Table 2).

TABLE 2. Comparison of symptom index positivity between the two methods of esophageal $\mathrm{pH}$ monitoring, positioned $3 \mathrm{~cm}$ above the lower esophageal sphincter

\begin{tabular}{lccccc}
\hline $\begin{array}{l}\text { Symptom } \\
\text { index }\end{array}$ & \multicolumn{2}{c}{ Conventional (day 1) } & \multicolumn{2}{c}{ Wireless (day 1) } & \multirow{2}{*}{$\boldsymbol{P}^{1}$} \\
\cline { 2 - 5 } & $\mathrm{n}$ & $\%$ & $\mathrm{n}$ & $\%$ & \\
\hline Negative & 8 & $32 \%$ & 7 & $28 \%$ & \\
Positive & 12 & $48 \%$ & 13 & $52 \%$ & \\
No symptom & 5 & $20 \%$ & 5 & $20 \%$ & 0.777 \\
Total & 25 & $100 \%$ & 25 & $100 \%$ & \\
\hline
\end{tabular}

${ }^{1}$ Bilateral proportion test $\left(\mathrm{H}_{\mathrm{o}}: \mathrm{p}_{1}=\mathrm{p}_{2}, \mathrm{H}_{1}: \mathrm{p}_{1} \neq \mathrm{p}_{2}\right)$; Conventional $=$ conventional esophageal $\mathrm{pH}$ monitoring; Wireless $=$ wireless esophageal $\mathrm{pH}$ monitoring.

The spontaneous detachment of the $\mathrm{pH}$ monitoring capsule from the esophageal wall was confirmed in all patients in the study by a lateral chest X-ray, on the 30th day after the capsule insertion. No patient experienced severe chest pain or any other symptom requiring endoscopic removal of the capsule.

\section{DISCUSSION}

The comparison between wireless and conventional esophageal $\mathrm{pH}$ monitoring was conducted at a level below the traditional level, by positioning the capsule and catheter sensors $3 \mathrm{~cm}$ above the superior border of the LES. Reasons for this choice included: changes in the mucosa due to GERD commonly occur next to the esophagogastric junction; feasibility study of inserting the capsule closest to this transition zone; and compare, at this level, GERD detection between the two types of $\mathrm{pH}$ monitoring sensors (capsule versus catheter).

The percentage of total reflux time considered normal for wireless $\mathrm{pH}$ monitoring (48h) varies from $4.4 \%$ to $5.3 \%$ according to the literature ${ }^{(24,33)}$. In this study, the same parameters of the conventional method $(5 \mathrm{~cm})$ were used; it is important to note that the main objective was to compare the detection of reflux, using both methods, at $3 \mathrm{~cm}$ above the LES.

Contraindications of the wireless $\mathrm{pH}$ monitoring system are limitations to the method and include: severe esophagitis, esophageal varices, bleeding, stenosis and obstruction of the gastrointestinal tract, the use of cardiac pacemakers and defibrillators. It should be noted that such conditions do not represent contraindications to the $\mathrm{pH}$ monitoring with a catheter. Magnetic resonance (MRI) is not recommended for 30 days after insertion of the capsule because of the risk of perforation, in case the capsule has not yet been completely eliminated. This restriction is also not applicable to $\mathrm{pH}$ monitoring with a catheter.

Complaints associated with heartburn and/or regurgitation was significant: $64 \%$ of patients had atypical complaints, and $76 \%$ had associated extraesophageal complaints. Nasi et al. ${ }^{(23)}$ observed that there was a prevalence of typical complaints in $49.7 \%$ of patients referred for the conventional $\mathrm{pH}$ monitoring, and prevalence of atypical and/or extraesophageal complaints in $50.3 \%$. The conventional $\mathrm{pH}$ monitoring study with two $\mathrm{pH}$ sensors (one in the distal esophagus and the other in the upper esophageal sphincter, or just above it), can be performed in patients whose main symptom is extraesophageal or globus sensation. Thus, a considerable group of patients (about half of the cases) would have restrictions to the use of the wireless $\mathrm{pH}$ monitoring system, since it is not possible to insert a second capsule in the upper esophageal sphincter or in the pharynx.

The finding of $4 \%$ of relevant technical failures during wireless $\mathrm{pH}$ monitoring supports literature's current data, that indicate failures in $4.1 \%$ to $5 \%$ of $\operatorname{cases}^{(2,9,26)}$. However, there was an improvement of this rate when compared to earlier studies that indicate failures from $11 \%$ to $13.3 \%(24,31,33)$, due to changes in equipment manufacture and increased time of vacuum suction of the mucosa, which enabled better fixation of the capsule. Early drop of the capsule occurred in the only patient who experienced diffuse esophageal spasm in the manometric study. The relationship between the two events is, however, debatable.

The conventional $\mathrm{pH}$ monitoring method has been considered the best diagnostic method of gastroesophageal acid reflux, offering sensitivity ranging from $79 \%$ to $96 \%$, specificity from $85 \%$ to $100 \%$, and $98 \%$ accuracy $(7,8,12,13,18,27,30)$. Pandolfino et al ${ }^{(24)}$, who pioneered the wireless $\mathrm{pH}$ monitoring method, reported a method's sensitivity ranging from $78.3 \%$ to $100 \%$, and specificity from $84.5 \%$ to $94.8 \%$, being very similar to those attributed to the conventional method.

The three concurrent studies reported in the literature indicated a greater rate of total reflux time in the conventional $\mathrm{pH}$ monitoring ${ }^{(4,10,25)}$. The authors of the first simultaneous study also observed a greater rate of supine and upright reflux time in the conventional method, stating that the wireless method has lower sensitivity when compared to the conventional method $^{(4)}$. However, in these studies the capsule was positioned with the aid of an endoscopic parameter at 5 or $6 \mathrm{~cm}$ above the squamocolumnar transitional zone $\mathrm{e}^{(4,10,25)}$. In this study, the capsule and the catheter were positioned with the aid of a manometric parameter at $3 \mathrm{~cm}$ above the upper border of the LES, showing different results: the three rates of reflux time (total, upright and supine) were significantly higher in the wireless $\mathrm{pH}$ monitoring. Perhaps the difference in the placement method of the $\mathrm{pH}$ sensors may have influenced the difference between our results and those reported in the literature.

There are possible explanations for the reflux detection differences between the methods: the logging interval of $\mathrm{pH}$ samples is different in each method (the wireless method registers samples every 6 seconds, while the conventional method does it every 4 seconds); the capsule positioning is 
fixed, while the catheter's varies in relation to the LES during swallowing; and the wireless method detects fewer reflux episodes, especially those of short duration, when compared to the conventional $\mathrm{pH}$ monitoring $(4,14,25)$.

When simultaneously comparing the first $24 \mathrm{~h}$ of the conventional method with those of the wireless method, there was an increase in the diagnosis of pathological GERD in $12 \%$ of cases $(64.0 \%$ vs $76.0 \%)$. Despite the fact that this difference did not reach statistical significance levels, the trend observed suggests that the wireless method may exhibit a greater diagnostic sensitivity when compared to the conventional $\mathrm{pH}$ monitoring.

Des Varannes et al. ${ }^{(4)}$ found a lower positivity in wireless $\mathrm{pH}$ monitoring compared to the conventional method $(22.6 \%$ vs $29.0 \%$ ), among clinical complaints and GER in the first $24 \mathrm{~h}$ using the symptom association probability. However, using the symptom index, we detected a higher positivity in the wireless method compared to the conventional method ( $52 \%$ vs $48 \%$ ). But none of the studies results reached statistical significance.

As for radiological control, Des Varannes et al. ${ }^{(4)}$ and Remes-Troche et al. ${ }^{(26)}$ observed spontaneous capsule detachment in all patients, during the first 14 days. While using the wireless method in 245 patients, with radiological control on the 14th day, Lin et al. ${ }^{(16)}$ observed that the capsule remained in $1 \%$ of cases. Considering this and the recommendation not to perform MRI in the first 30 days, radiological control was carried out in this study after 1 month of capsule insertion. After this time, if the capsule was still in place, an endoscopy withdrawal would be scheduled.

There was no need for capsule removal in any patient studied by Remes-Troche et al. ${ }^{(26)}$, which was also the case of the present study. However, there are reports of endoscopic capsule removal in $1.4 \%$ to $3.5 \%$ of cases, in large samples (90 to 245 patients $)^{(1,2)}$. The most common reason for withdrawal was severe chest pain ${ }^{(24)}$. Other complications of the wireless $\mathrm{pH}$ monitoring reported in the literature are: esophageal perforation during insertion, esophageal ulcer, capsule migra- tion to the nasopharynx after cough, and capsule retention in a colon diverticulum ${ }^{(6,32)}$. Because of this complication, we believe a simple radiography of the abdomen should be required for complete evaluation of the capsule elimination.

In a review article ${ }^{(11)}$ comparing GER monitoring methods (bile, $\mathrm{pH}$ and MII-pH monitoring), the wireless method is described as having better tolerability and greater sensitivity with regard to the conventional method. MII-pH monitoring significantly contributes to the understanding of the GERD pathogenesis, however it still has a very limited availability in social clinical care.

Finally, it is important to emphasize that a higher reflux detection rate by wireless $\mathrm{pH}$ monitoring was observed in this study, when compared to the conventional method. There was a slight advantage of the wireless method over the conventional method in the diagnosis of pathological GER, and in the ability to relate clinical complaints with GER, although without statistical significance levels.

\section{CONCLUSIONS}

Considering the conditions of this study, we may conclude that:

1. There is no significant difference between esophageal $\mathrm{pH}$ monitoring with and without catheter in terms of occurrence of relevant technical failures during monitoring;

2. The wireless $\mathrm{pH}$ monitoring detects reflux at significantly higher levels than conventional $\mathrm{pH}$ monitoring, when it comes to the three variables considered: total reflux time rate, reflux rate in upright and in supine positions;

3. There is no significant difference between the two methods of $\mathrm{pH}$ monitoring on the ability of diagnosing pathological gastroesophageal reflux;

4. The conventional esophageal $\mathrm{pH}$ monitoring and the wireless $\mathrm{pH}$ monitoring have similar capabilities of relating clinical complaints with gastroesophageal reflux.

Azzam RS, Sallum RAA, Brandão JF, Navarro-Rodriguez T, Nasi A. Estudo comparativo de duas modalidades de mensuração do refluxo gastroesofágico: pHmetria esofágica convencional e pHmetria sem cateter. Arq Gastroenterol. 2012;49(2):107-112.

RESUMO - Contexto - A pHmetria esofágica é considerada o melhor método diagnóstico do refluxo ácido gastroesofágico. Contudo, é bastante incômoda e restringe consideravelmente as atividades cotidianas do paciente. A pHmetria sem cateter foi desenvolvida para contornar tais limitações. Objetivo - Comparar as primeiras 24 horas das pHmetrias convencional e sem cateter, posicionadas a $3 \mathrm{~cm}$ acima do esfíncter inferior do esôfago, em relação à: ocorrência de falhas técnicas relevantes, capacidade de detecção do refluxo e capacidade de relacionar as queixas clínicas com o refluxo. Métodos - Foram estudados, de modo prospectivo, 25 pacientes encaminhados para pHmetria esofágica, com sintomas típicos da doença do refluxo gastroesofágico, submetidos a entrevista clínica, endoscopia digestiva, manometria esofágica e realização, com período inicial simultâneo, de pHmetrias com cateter por 24 horas e com cápsula por 48 horas. Resultados - Houve queda precoce da cápsula em um paciente (4\%) e nenhuma falha técnica na $\mathrm{pHmetria}$ com cateter $(P=0,463)$. As percentagens de tempo de refluxo (total, ortostático e supino) foram mais elevadas na pHmetria sem cateter $(P<0,05)$. Refluxo gastroesofágico patológico foi diagnosticado em $16(64,0 \%)$ pacientes com o cateter e em $19(76,0 \%)$ com a cápsula $(P=0,355)$. O índice de sintomas foi positivo em $12(48 \%)$ pacientes na pHmetria com cateter e em $13(52 \%)$ na pHmetria sem cateter $(P=0,777)$. Conclusões - 1) Não há diferença significante entre as duas modalidades de pHmetria (cápsula vs cateter), em relação à ocorrência de falhas técnicas relevantes durante o exame; 2) A pHmetria sem cateter detecta refluxo em percentagens superiores às detectadas pela pHmetria convencional; 3) Os dois métodos de pHmetria têm capacidades semelhantes de diagnóstico de refluxo gastroesofágico patológico e capacidades semelhantes de relacionar as queixas clínicas com o refluxo gastroesofágico.

DESCRITORES - Refluxo gastroesofágico. Esofagite péptica. Monitoramento do pH esofágico. 


\section{REFERENCES}

1. Ahlawat SK, Novak DJ, Williams DC, Maher KA, Barton F, Benjamin SB. Day-to-day variability in acid reflux patterns using the BRAVO $\mathrm{pH}$ monitoring system. J Clin Gastroenterol. 2006;40:20-4.

2. Bhat YM, McGrath KM, Bielefeldt K. Wireless esophageal $\mathrm{pH}$ monitoring: new technique means new questions. J Clin Gastroenterol. 2006;40:116-21.

3. Brandalise, A. Variantes técnicas de mensuração da pressão do esfíncter inferior do esôfago, ao estudo manométrico, e sua relação com o refluxo gastroesofágico, avaliado por pHmetria esofágica prolongada [dissertação]. São Paulo: Faculdade de Medicina, Universidade de São Paulo; 2001.

4. des Varannes SB, Mion F, Ducrotté P, Zerbib F, Denis P, Ponchon T, Thibault R, Galmiche JP. Simultaneous recordings of oesophageal acid exposure with conventional $\mathrm{pH}$ monitoring and a wireless system (Bravo). Gut. 2005;54:1682-6.

5. DeVault KR, Castell DO. Current diagnosis and treatment of gastroesophageal reflux disease. Mayo Clin Proc. 1994;69:867-76.

6. Fajardo NR, Wise JL, Locke GR 3rd, Murray JA, Talley NJ. Esophagea perforation after placement of wireless Bravo $\mathrm{pH}$ probe. Gastrointest Endosc. 2006;63:184-5.

7. Fass R, Hell R, Sampliner RE, Pulliam G, Graver E, Hartz V, Johnson C, Jaffe $\mathrm{P}$. Effect of ambulatory 24-hour esophageal $\mathrm{pH}$ monitoring on reflux-provoking activities. Dig Dis Sci. 1999;44:2263-9.

8. Fuchs KH, DeMeester TR, Albertucci M. Specificity and sensitivity of objective diagnosis of gastroesophageal reflux disease. Surgery. 1987;102:575-80.

9. Gillies RS, Stratford JM, Booth MI, Dehn TC. Oesophageal pH monitoring using the Bravo catheter-free radio capsule. Eur J Gastroenterol Hepatol. 2007;19:57-63.

10. Hakanson BS, Berggren P, Granqvist S, Ljungqvist O, Thorell A. Comparison of wireless 48 -h (Bravo) versus traditional ambulatory 24 -h esophageal $\mathrm{pH}$ monitoring. Scand J Gastroenterol. 2009;44:276-83.

11. Hirano I. Review article: modern technology in the diagnosis of gastro-oesophageal reflux disease - Bilitec, intraluminal impedance and Bravo capsule $\mathrm{pH}$ monitoring. Aliment Pharmacol Ther. 2006;23:12-24.

12. Jamieson JR, Stein HJ, DeMeester TR, Bonavina L, Schwizer W, Hinder RA, Albertucci M. Ambulatory 24-h esophageal $\mathrm{pH}$ monitoring: normal values, optimal thresholds, specificity, sensitivity, and reproducibility. Am J Gastroenterol. 1992;87:1102-11.

13. Johnsson F, Joelsson B, Isberg PE. Ambulatory 24 hour intraesophageal pH-monitoring in the diagnosis of gastroesophageal reflux disease. Gut. 1987;28:1145-50.

14. Kahrilas PJ, Quigley EM. Clinical esophageal $\mathrm{pH}$ recording: a technical review for practice guideline development. Gastroenterology. 1996;110:1982-96.

15. Klauser AG, Heinrich C, Schindlbeck NE, Müller-Lissner SA. Is long-term esophageal pH monitoring of clinical value? Am J Gastroenterol. 1989;84:362-5.

16. Lin E, Waring JP, Ramaswamy A. Analysis of 245 consecutive studies using 48-hour wireless $\mathrm{pH}$ (Bravo) probes for GERD evaluation. Gastroenterology. 2003;124:A689.

17. Masclee AA, de Best AC, de Graaf R, Cluysenaer OJ, Jansen JB. Ambulatory 24hour $\mathrm{pH}$-metry in the diagnosis of gastroesophageal reflux disease. Determination of criteria and relation to endoscopy. Scand J Gastroenterol. 1990;25:225-30.

18. Mattioli S, Pilotti V, Spangaro M, Grigioni WF, Zannoli R, Felice V, Conci A Gozzetti G. Reliability of 24-hour home esophageal $\mathrm{pH}$ monitoring in diagnosis of gastroesophageal reflux. Dig Dis Sci. 1989;34:71-8.
19. Mearin F, Balboa A, Dot J, Maldonado O, Malagelada JR. How standard is a standard day during a standard ambulatory 24-hour esophageal $\mathrm{pH}$ monitoring? Scan J Gastroenterol. 1998;33:583-5.

20. Moraes-Filho J, Cecconello I, Gama-Rodrigues J, Castro LP, Henry MA, Meneghelli UG, Quigley E, Brazilian Consensus Group. Brazilian consensus on gastroesophageal reflux disease: proposals for assessment, classification and management. Am J Gastroenterol. 2002;97:241-8.

21. Nasi A, Parada AA, Cecconello I, Zilberstein B, Pinotti HW. pHmetria esofágica prolongada: técnica, indicações e resultados. GED. 1990;9:126.

22. Nasi A, Filho JP, Zilberstein B, Cecconello I, Gama-Rodrigues JJ, Pinotti HW. Gastroesophageal reflux disease: clinical, endoscopic, and intraluminal esophageal pH monitoring evaluation. Dis Esophagus. 2001;14:41-9.

23. Nasi A, Frare Rde C, Brandão JF, Falcão AM, Michelsohn NH, Sifrim D. [Comparative prospective study of two positioning modes of 24-hour esophageal $\mathrm{pH}$ monitoring: by esophageal manometry and by the $\mathrm{pH}$ step-up technique]. Arq Gastroenterol. 2008;45:261-7.

24. Pandolfino JE, Richter JE, Ours T, Guardino JM, Chapman J, Kahrilas PJ. Ambulatory esophageal $\mathrm{pH}$ monitoring using a wireless system. Am J Gastroenterol. 2003;98:740-9.

25. Pandolfino JE, Zhang Q, Schreiner MA, Ghosh S, Roth MP, Kahrilas PJ. Acid reflux event detection using the Bravo wireless versus the Slimline catheter $\mathrm{pH}$ systems: why are the numbers so different? Gut. 2005;54:1687-92.

26. Remes-Troche JM, Ibarra-Palomino J, Carmona-Sánchez RI, Valdovinos MA Performance, tolerability, and symptoms related to prolonged $\mathrm{pH}$ monitoring using the Bravo system in Mexico. Am J Gastroenterol. 2005;100:2382-6.

27. Schindlbeck NE, Heinrich C, König A, Dendorfer A, Pace F, Müller-Lissner SA. Optimal thresholds, sensitivity, and specificity of long-term $\mathrm{pH}$-metry for the detection of gastroesophageal reflux disease. Gastroenterolgy. 1987;93:85-90.

28. Schlesinger PK, Donahue PE, Schmid B, Layden TJ. Limitations of 24-hou intraesophageal $\mathrm{pH}$ monitoring in the hospital setting. Gastroenterology. 1985;89:797-804

29. Sonnenberg A, El-Serag HB. Clinical epidemiology and natural history of gastroesophageal reflux disease. Yale J Biol Med. 1999;72:81-92.

30. Vitale GC, Sadek S, Tulley FM, Rimmer AR, Hunter BE, Phelan J, Cuschieri A Computerized 24-hour esophageal $\mathrm{pH}$ monitoring: a new ambulatory technique using radiotelemetry. J Lab Clin Med. 1985;105:686-93.

31. Ward EM, Devault KR, Bouras EP, Stark ME, Wolfsen HC, Davis DM, Nedrow SI, Achem SR. Successful oesophageal $\mathrm{pH}$ monitoring with a catheter-free system. Aliment Pharmacol Ther. 2004;19:449-54.

32. Wells CD, Heigh RI, Burdick GE, Moirano MM, Fleischer DE. Symptomatic esophageal ulceration caused by a Bravo wireless $\mathrm{pH}$ probe and subsequent endoscopic removal of the probe using a retrieval net. Endoscopy. 2006;38(Supp 2):E97.

33. Wenner J, Johnsson F, Johansson J, Oberg S. Wireless oesophageal pH monitoring feasibility, safety and normal values in healthy subjects. Scand J Gastroenterol. 2005;40:768-74.

34. Wiener GJ, Richter JE, Cooper JB, Wu WC, Castell DO. The symptom index: a clinically important parameter of ambulatory 24 -hour esophageal $\mathrm{pH}$ monitoring. Am J Gastroenterol. 1988:83:358-61. 